\title{
EFEKTIVITAS SKYLIGHT SEBAGAI BUKAAN PENCAHAYAAN ALAMI PADA MASJID
}

\author{
Christy Vidiyanti*, Suherman
}

*) Corresponding author email : christy.vidiyanti@mercubuana.ac.id

Program Studi Arsitektur, Fakultas Teknik, Universitas Mercu Buana

Article info

MODUL vol 20 no 2, issues period 2020

Doi $\quad: 10.14710 / \mathrm{mdl} .20 .2 .2020 .120-125$

Received : 19 juni 2020

Revised : 2 oktober 2020

Accepted : 5 oktober 2020

\begin{abstract}
Skylight sebagai salah satu jenis bukaan atas dapat menjadi salah satu strategi dalam memasukkan cahaya alami ke ruang yang tidak dapat dijangkau oleh sistem pencahayaan samping. Masjid Jami'e Darussalam merupakan salah satu masjid yang menggunakan skylight. Penggunaan skylight menjadi dilema karena cahaya matahari langsung dapat masuk kedalam ruang yang dapat menyebabkan silau pada ruang. Penelitian ini akan mengkaji skylight sebagai salah satu strategi dalam sistem pencahayaan alami pada masjid. Masjid biasanya dirancang dengan pencahayaan rendah, namun pada masjid Jami'e Darussalam terdapat skylight yang dapat menghasilkan pencahayaan yang tinggi. Hal ini perlu dikaitkan dengan kenyamanan visual dari pengguna. Tujuan dari penelitian ini adalah untuk mengetahui efektivitas skylight sebagai bukaan pencahayaan alami dalam menghasilkan kuantitas dan kualitas pencahayaan pada masjid; dan untuk mengetahui kenyamanan visual yang dirasakan oleh responden pada masjid Jami'e Darussalam. Metode yang dipakai adalah metode evaluatif dengan pendekatan kuantitatif. Hasil penelitian menunjukkan penggunaan skylight walaupun menghasilkan tingkat pencahayaan yang tinggi, namun tidak berpotensi menimbulkan silau. Hal tersebut didukung oleh kenyamanan visual yang dirasakan oleh pengguna Masjid Jami'e Darussalam.
\end{abstract}

Keywords: skylight; bukaan cahaya; pencahayaan alami; masjid

Christy Vidiyanti, Suherman

\section{PENDAHULUAN}

Masjid sangat banyak ditemui di Indonesia karena mayoritas penduduknya beragama Islam. Masjid di Indonesia memiliki beragam desain. Bangunan masjid sebagai tempat ibadah harus dapat menciptakan kenyamanan bagi penggunanya. Hakekat dari mesjid adalah tempat melakukan segala aktivitas yang berkaitan dengan kepatuhan kepada Allah semata. Oleh karena itu, mesjid dapat diartikan lebih jauh, bukan hanya sekedar tempat bersujud, pensucian, tempat shalat dan bertayammum, namun juga sebagai tempat melaksanakan segala aktivitas kaum muslim berkaitan dengan kepatuhan kepada Allah SWT (Massikki, 2011). Manusia dapat melaksanakan ibadah dengan baik apabila dapat didukung dari lingkungannya ibadahnya, salah satunya dengan menciptakan penerangan yang baik.

Secara umum, bangunan masjid merupakan bangunan bentang lebar. Salah satu permasalahan bangunan bentang lebar adalah sistem pencahayaan alami dalam ruang. Hal ini karena bangunan bentang lebar memiliki dimensi yang dalam sehingga cahaya alami tidak dapat menjangkau ruang yang dalam. Dalam lingkup estetika, pencahayaan dapat digunakan untuk menciptakan efek tertentu yang dapat mendukung kualitas interior. Pencahayaan selain untuk memenuhi efek estetika juga harus dapat mendukung fungsi bangunan. Bangunan masjid memiliki prasyarat minimum pencahayaan pada ruang ibadah adalah sebesar 200 lux (SNI 6197:2011). Perancangan pencahayaan alami merupakan salah satu yang menentukan kualitas rancangan suatu bangunan. Pada dasarnya suatu objek benda atau furniture dapat memantulkan cahaya berdasarkan dari jenis material, warna, dan tekstur.

Selain aspek kuantitas dan kualitas pencahayaan perlu juga memperhatikan aspek efisiensi konsumsi energi dengan memanfaatkan cahaya alam untuk mendapatkan keuntungan yang besar. Cahaya alam yang masuk melalui jendela, dapat dipakai sebagai sumber 
pencahayaan di dalam bangunan sekaligus upaya untuk menghemat energi (Irianto, 2006). Wisnu (2017) menyatakan bahwa dengan nilai transparansi kaca $90 \%$ dinilai efektif untuk meningkatkan intensitas cahaya alami.

Pencahayaan alami sebagai salah satu faktor penting dalam perancangan sebuah bangunan. Perencanaan sistem pencahayaan alami harusnya direncanakan menyatu dengan perancangan bangunan. Pencahayaan alami berguna untuk mendukung fungsi sebuah bangunan dapat berjalan dengan baik, karena pencahayaan yang cukup dapat membuat sebuah objek bisa dilihat dengan baik. Heschong (2002) menyatakan bahwa terdapat hubungan positif antara pencahayaan alami dan peningkatan kinerja. Pencahayaan alami juga dapat meningkatkan kepuasan penghuni. Orang dengan akses ke jendela memiliki kepuasan yang lebih tinggi dari orang tanpa akses ke jendela. Pencahayaan alami juga mampu membantu dalam proses mengatasi stress (Veitch, 2006).

Kualitas pencahayaan alami pada masjid di daerah perkotaan padat penduduk belum menjamin kenyamanan di setiap sisi ruangan masjid. Pencapaian kenyamanan hanya didapatkan pada beberapa titik di dalam ruangan masjid. Disamping dipengaruhi oleh jenis dan ukuran bukaan, kualitas pencahayaaan alami juga dipengaruhi oleh posisi masjid terhadap bangunan sekitarnya (Zainurrahman, 2012). Lubang cahaya yang terlalu besar, dapat mengakibatkan cahaya matahari masuk dalam jumlah besar, yang sekaligus membawa radiasi masuk ke dalam bangunan. Hal ini mengakibatkan adanya dilema bahwa sinar matahari yang masuk kedalam bangunan akan mempengaruhi kondisi termal ruang. Sehingga dibutuhkan adanya kondisi dimana pencahayaan alami dan penghawaan alami pada ruang menjadi seimbang (Vidiyanti, 2018). Terang dan gelap sebuah ruang bukan hanya dinilai dari pencahayaan ruang secara aktual, namun juga dari pencahayaan lingkungan yang dapat memenuhi kebutuhan informasi visual.

Pertiwi (2018) menyatakan bahwa terdapat 3 aspek guna memenuhi kenyamanan visual. Pertama, aspek tingkat pencahayaan minimum yang memenuhi kebutuhan tugas visual tertentu. Kedua, aspek kenyamanan visual. Dan ketiga adalah aspek pemodelan dari permukaan-permukaan yang ada di dalam ruangan masjid. Meskipun terjadi pengurangan secara signifikan dalam transmisi cahaya, penghuni yang bekerja di zona perimeter umumnya menganggap tingkat pencahayaan alami yang tersedia adalah cukup, bahkan ketika tingkat pencahayaan alami di bawah ambang batas yang direkomendasikan (Konis, 2013).
Bangunan masjid Jami'e Darussalam memiliki bukaan cahaya dengan tipe skylight yang menyatu dengan bukaan sampingnya. Hal ini membuat bangunan ini bukan hanya menerima cahaya matahari difus, tapi juga menerima cahaya matahari langsung. Pencahayaan yang baik dapat mendukung fungsi dalam bangunan berjalan dengan baik. Bangunan masjid Jami'e Darussalam memiliki tipe bukaan skylight yang menyatu dengan bukaan samping. Hal ini dapat mengakibatkan masuknya cahaya matahari langsung. Cahaya matahari langsung seringkali dihindari karena dapat mengakibatkan silau. Penelitian ini mencoba mengkaji efektivitas skylight sebagai bukaan pada masjid ini.

Pertanyaan penelitian yang diajukan pada penelitian ini adalah bagaimana efektivitas skylight sebagai bukaan pencahayaan alami dalam menghasilkan kuantitas dan kualitas pencahayaan pada masjid dan bagaimana kenyamanan visual yang dirasakan oleh responden pada masjid Jami'e Darussalam.

\section{METODE}

Penelitian ini meneliti pencahayaan alami pada Masjid Jami'e Darussalam. Masjid ini memiliki lahan seluas 819 m2, dan terletak di Jalan Kebon Melati Tanah Abang Jakarta Pusat, Masjid Jami'e Darussalam ini terdiri dari ruangan sholat area atas untuk pria dan area bawa khusus untuk wanita, keunikan bangunan ini adalah massa ruang dengan bentuk segitiga dan dilapisi dengan facade kaca.

Penelitian ini akan menguji kinerja kuantitas dan kualitas pencahayaan alami yang dihasilkan oleh skylight pada ruang sholat masjid Jami'e Darussalam. Penelitian ini merupakan penelitian evaluatif dengan pendekatan kuantitatif.

Bagian yang penting dalam suatu evaluasi adalah adanya suatu tujuan atau keadaan yang diharapkan, dan kemudian tujuan tersebut dinilai dengan melakukan evaluasi. Penilaian dalam evaluasi ini tidak saja menyangkut perubahan yang direncanakan, akan tetapi juga perubahan-perubahan yang tidak direncanakan. Oleh karena itu evaluasi akan dapat dilaksanakan dengan baik apabila dalam program dicantumkan tujuan yang jelas, sehingga mampu mendefinisikan hasil yang diharapkan untuk dicapai melalui kerangka konseptual metodologi pada penelitian evaluasi (Kantun, 2017).

Metode evaluatif yang akan digunakan adalah dengan mengukur kinerja dari skylight dalam memenuhi kuantitas pencahayaan alami yang disyaratkan dan dalam menghasilkan kualitas pencahayaan yang baik. Selain menilai kinerja skylight berdasarkan persyaratan yang ada, kinerja skylight juga dinilai berdasarkan penilaian responden dalam menghasilkan kualitas visual. Secara rinci metode evaluatif yang dilakukan dalam penelitian ini dapat dilihat pada gambar dibawah. 


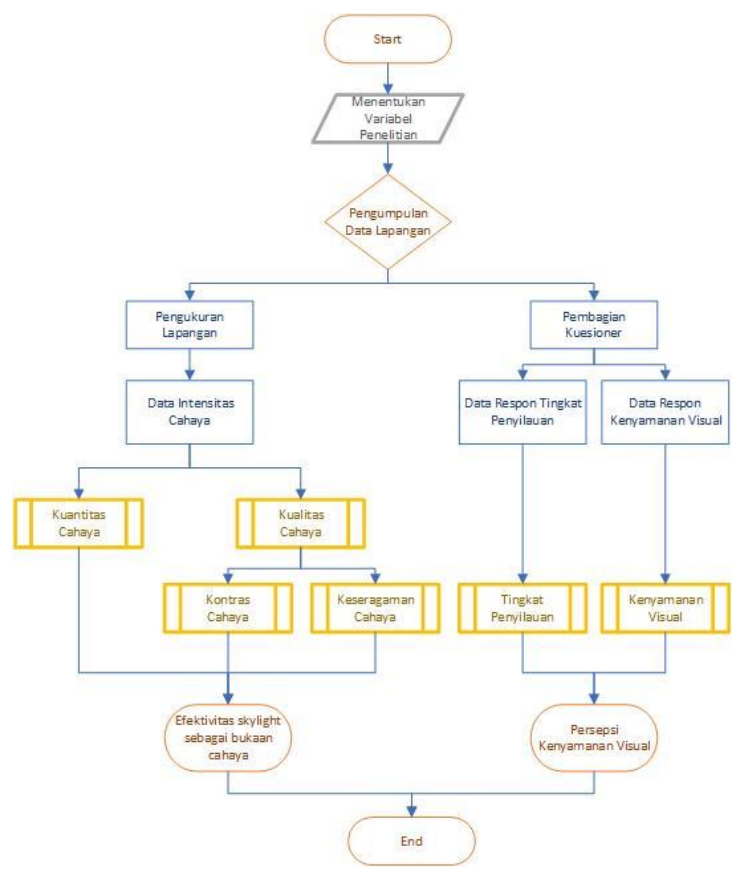

Figure 1. Tahapan penelitian

Metode pengukuran lapangan mengikuti prosedur berdasarkan SNI 16-7062-2004 tentang Pengukuran intensitas penerangan di tempat kerja ditentukan kriteria dalam penentuan ukur. Pengukuran intensitas penerangan ini memakai alat luxmeter yang telah dikalibrasi. Masjid Jami'e Darussalam memiliki luas ruang ibadah sebesar 70 meter persegi, sehingga kriteria titik ukur yang diambil adalah pada per 3 meter untuk setiap titik ukur.

\section{HASIL ANALISIS}

\section{Intensitas Pencahayaan Alami}

Pada subbab ini akan dibahas terkait dengan intensitas pencahayaan alami berupa kuantitas pencahayaan dan kualitas pencahayaan.

Table 1. Tingkat Pencahayaan di Masjid Jami'e Darussalam (dalam satuan lux)

\begin{tabular}{|l|r|r|r|r|r|}
\hline $\begin{array}{l}\text { Titik } \\
\text { Ukur }\end{array}$ & $\begin{array}{l}\text { Pukul } \\
\text { 08.00 }\end{array}$ & $\begin{array}{l}\text { Pukul } \\
\mathbf{1 0 . 0 0}\end{array}$ & $\begin{array}{l}\text { Pukul } \\
\mathbf{1 2 . 0 0}\end{array}$ & $\begin{array}{l}\text { Pukul } \\
\mathbf{1 4 . 0 0}\end{array}$ & $\begin{array}{l}\text { Pukul } \\
\mathbf{1 6 . 0 0}\end{array}$ \\
\hline 1 & 433 & 1102 & 639 & 738 & 853 \\
\hline 2 & 1286 & 1232 & 1550 & 1714 & 1684 \\
\hline 3 & 1424 & 1167 & 2294 & 1134 & 962 \\
\hline 4 & 974 & 1353 & 1398 & 1374 & 1212 \\
\hline 5 & 611 & 339 & 433 & 344 & 330 \\
\hline 6 & 670 & 628 & 663 & 492 & 407 \\
\hline 7 & 1187 & 1600 & 1399 & 1711 & 1606 \\
\hline 8 & 701 & 723 & 1139 & 994 & 861 \\
\hline 9 & 775 & 1059 & 2303 & 1123 & 972 \\
\hline 10 & 503 & 959 & 1344 & 1237 & 1058 \\
\hline $\begin{array}{l}\text { Rata- } \\
\text { rata }\end{array}$ & $\mathbf{8 5 6}$ & $\mathbf{1 0 1 6}$ & $\mathbf{1 3 1 6}$ & $\mathbf{1 0 8 6}$ & $\mathbf{9 9 5}$ \\
\hline
\end{tabular}

Selanjutnya ke 10 titik tersebut selanjutnya akan dibahas menjadi 3 zona, yaitu zona utara (kanan), zona selatan (kiri), dan zona tengah.

Table 2. Tingkat Pencahayaan Per Zona

\begin{tabular}{|l|r|r|r|r|r|}
\hline \multicolumn{7}{|c|}{ Nilai tingkat pencahayaan per zona (dalam satuan } \\
\multicolumn{7}{|c|}{ lux) } \\
\hline \multicolumn{1}{|c|}{ Zona } & $\begin{array}{c}\text { Pukul } \\
\mathbf{0 8 . 0 0}\end{array}$ & $\begin{array}{c}\text { Pukul } \\
\mathbf{1 0 . 0 0}\end{array}$ & $\begin{array}{c}\text { Pukul } \\
\mathbf{1 2 . 0 0}\end{array}$ & $\begin{array}{c}\text { Pukul } \\
\mathbf{1 4 . 0 0}\end{array}$ & $\begin{array}{c}\text { Pukul } \\
\mathbf{1 6 . 0 0}\end{array}$ \\
\hline $\begin{array}{l}\text { Zona } \\
\text { Utara }\end{array}$ & 888 & 1304 & 1380 & 1441 & 1292 \\
\hline $\begin{array}{l}\text { Zona } \\
\text { Selatan }\end{array}$ & 866 & 765 & 1041 & 1017 & 958 \\
\hline $\begin{array}{l}\text { Zona } \\
\text { Tengah }\end{array}$ & 826 & 989 & 1475 & 872 & 799 \\
\hline
\end{tabular}

Mengacu pada tabel diatas, terlihat bahwa pada keseluruhan waktu, zona utara memiliki tingkat pencahayaan yang lebih tinggi kecuali pada pukul 12.00. Hal ini terjadi karena pada area utara, tingkat penghalang matahari pada bagian luar masjid sangat rendah. Sehingga sinar matahari langsung dapat masuk ke area masjid. Sedangkan pada jam 12.00, tingkat pencahayaan tertinggi berada pada zona tengah. Hal ini karena pada jam 12 siang, posisi matahari berada di tengah sehingga sinar matahari langsung masuk ke ruang masjid melalui skylight.

Table 3. Kualitas Pencahayaan Alami

\begin{tabular}{|l|c|c|c|c|c|}
\hline \multicolumn{7}{|c|}{ Kriteria } & $\begin{array}{c}\text { Pukul } \\
\mathbf{0 8 . 0 0}\end{array}$ & $\begin{array}{c}\text { Pukul } \\
\mathbf{1 0 . 0 0}\end{array}$ & $\begin{array}{c}\text { Pukul } \\
\mathbf{1 2 . 0 0}\end{array}$ & $\begin{array}{c}\text { Pukul } \\
\mathbf{1 4 . 0 0}\end{array}$ & $\begin{array}{c}\text { Pukul } \\
\mathbf{1 6 . 0 0}\end{array}$ \\
\hline $\begin{array}{l}\text { Kontras } \\
\text { Cahaya }\end{array}$ & 0.30 & 0.21 & 0.19 & 0.20 & 0.20 \\
\hline $\begin{array}{l}\text { Keseragaman } \\
\text { Cahaya }\end{array}$ & 0.51 & 0.33 & 0.33 & 0.32 & 0.33 \\
\hline
\end{tabular}

Berdasarkan SNI, suatu pencahayaan yang baik dapat dikatakan bila tidak terjadi kontras pencahayaan yaitu apabila terjadi perbedaan cahaya sebesar 1:40 atau setara dengan 0.025. Sehingga, pada Masjid Jami'e Darussalam, dikeseluruhan waktu tidak berpotensi menghasilkan kontras pencahayaan.

Sedangkan keseragaman cahaya, untuk menghasilkan pencahayaan yang seragam, maka minimum nilai keseragaman cahaya adalah 0.6. Sedangkan Masjid Jami'e Darussalam memiliki nilai dibawah standar keseragaman cahaya. Namun nilai keseragaman cahaya pada masjid ini tidak memiliki selisih yang tinggi dibandingkan dengan standar. 


\section{Tingkat Penyilauan}

Untuk mengetahui dimana spot silau pada Masjid Jami'e Darussalam, maka responden akan di bagikan kuesioner tingkat penyilauan. Dalam pengisian kuesioner tersebut responden akan diajak mengelilingi area ibadah dan akan berhenti sesuai zona yang tercantum pada lembar kuesioner.

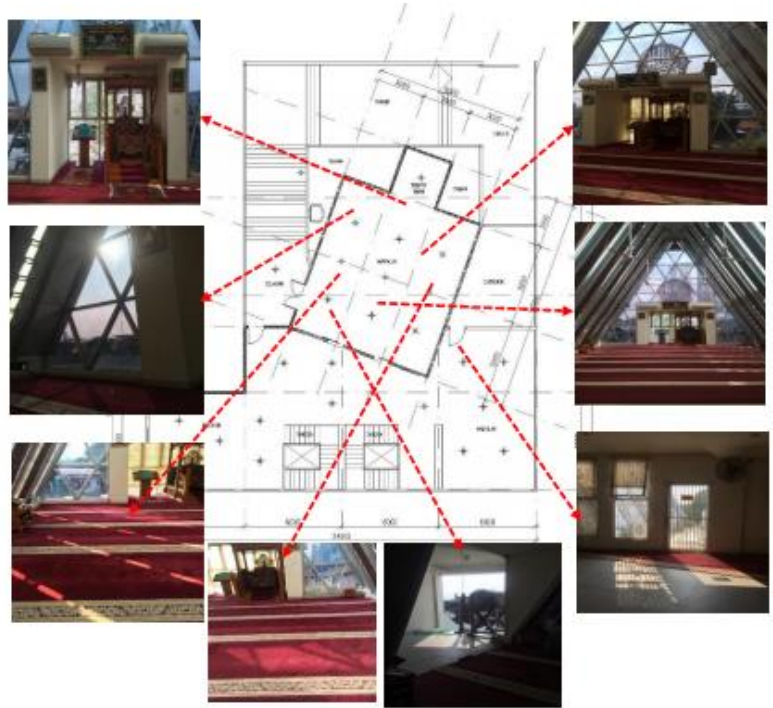

Figure 2. Pemetaan pembagian kuesioner zona spot silau

Hasil persepsi pada setiap spot tersebut kemudian di hitung menjadi tingkat penyilauan pada Masjid Jami'e Darussalam berdasarkan kategori interval tingkat kenyamanan.

Table 4. Tingkat Penyilauan pada Masjid Jami'e Darussalam

\begin{tabular}{|c|c|c|c|}
\hline No & $\begin{array}{c}\text { Nilai } \\
\text { Interval }\end{array}$ & Kategori Silau & $\begin{array}{c}\text { Kategori } \\
\text { Kenyamanan }\end{array}$ \\
\hline 1 & $1.00-1.80$ & Sangat Tidak Silau & Nyaman \\
\hline 2 & $1.81-2.60$ & Tidak Silau & Nyaman \\
\hline 3 & $2.61-3.40$ & Netral & Netral \\
\hline 4 & $3.41-4.20$ & Silau & Tidak Nyaman \\
\hline 5 & $4.21-5.00$ & Sangat Silau & Tidak Nyaman \\
\hline
\end{tabular}

Selanjutnya akan dihitung nilai tingkat penyilauan pada berbagai spot di Masjid Jami'e Darussalam. Setelah itu akan diberikan hasil pengkategorian tingkat penyilauan dan tingkat kenyamanan pada Masjid Jami'e Darussalam.
Table 5. Tingkat Penyilauan pada Masjid Jami’e Darussalam

\begin{tabular}{|c|c|c|c|c|}
\hline No & Spot & $\begin{array}{c}\text { Nilai } \\
\text { Tingkat } \\
\text { Penyilauan }\end{array}$ & $\begin{array}{c}\text { Tingkat } \\
\text { Silau }\end{array}$ & Kenyamanan \\
\hline 1 & Spot A & 2.60 & $\begin{array}{c}\text { Tidak } \\
\text { Silau }\end{array}$ & Nyaman \\
\hline 2 & Spot B & 3.52 & Silau & $\begin{array}{c}\text { Tidak } \\
\text { Nyaman }\end{array}$ \\
\hline 3 & Spot C & 2.56 & $\begin{array}{c}\text { Tidak } \\
\text { Silau }\end{array}$ & Nyaman \\
\hline 4 & Spot D & 2.96 & Netral & Netral \\
\hline 5 & Spot E & 3.00 & Netral & Netral \\
\hline 6 & Spot F & 2.36 & $\begin{array}{c}\text { Tidak } \\
\text { Silau }\end{array}$ & Nyaman \\
\hline 7 & Spot G & 2.80 & Netral & Nyaman \\
\hline \multicolumn{2}{|c|}{$\begin{array}{r}\text { RATA- } \\
\text { RATA }\end{array}$} & $\mathbf{2 . 8 3}$ & Netral & Nyaman \\
\hline
\end{tabular}

Berdasarkan tabel di atas dapat diketahui bahwa hanya spot B yang dirasakan responden merasa tidak nyaman karena responden merasa silau. Sedangkan pada spot lainnya menghasilkan persepsi nyaman karena kondisi tingkat penyilauan adalah netral dan tidak silau. Secara rata-rata, Masjid Jami'e Darussalam tidak dirasakan silau oleh responden. Hal ini sejalan dengan hasil pengukuran bahwa Masjid Jami'e Darussalam tidak menghasilkan kontras pencahayaan.

\section{Kenyamanan Visual}

Pada subbab ini akan dibahas terkait dengan persepsi kenyamanan visual berupa kenyamanan visual untuk melihat dan kenyamanan visual untuk beraktivitas melalui metode kuesioner.

Table 6. Tabel Rekapitulasi Kenyamanan Visual dalam Melihat

\begin{tabular}{|l|l|c|l|}
\hline Kode & \multicolumn{1}{|c|}{ Pertanyaan } & Nilai & Kategori \\
\hline A.1 & $\begin{array}{l}\text { Pencahayaan alami } \\
\text { yang masuk ke dalam } \\
\text { masjid cukup untuk } \\
\text { melihat keadaan } \\
\text { sekitar }\end{array}$ & 3.00 & Netral \\
\hline A.2 & $\begin{array}{l}\text { Pencahayaan alami } \\
\text { yang anda rasakan } \\
\text { pada saat melihat } \\
\text { keadaan di luar }\end{array}$ & 2.92 & Netral \\
\hline A.3 & $\begin{array}{l}\text { Penglihatan anda } \\
\text { ketika cahaya } \\
\text { matahari sore } \\
\text { memantul ke jendela }\end{array}$ & 2.44 & Nyaman \\
\hline A.4 & $\begin{array}{l}\text { Pencahayaan alami } \\
\text { yang masuk ke lantai } \\
\text { masjid membuat mata } \\
\text { anda silau }\end{array}$ & 3.12 & Netral \\
\hline
\end{tabular}




\begin{tabular}{|l|l|c|l|}
\hline Kode & \multicolumn{1}{|c|}{ Pertanyaan } & Nilai & Kategori \\
\hline A.5 & $\begin{array}{l}\text { Pencahayaan alami } \\
\text { yang masuk dari atap } \\
\text { skylight membuat } \\
\text { mata anda silau }\end{array}$ & 2.88 & Netral \\
\hline A.6 & $\begin{array}{l}\text { Perpaduan warna } \\
\text { dinding dengan } \\
\text { cahaya yang masuk } \\
\text { ke dalam membuat } \\
\text { anda silau }\end{array}$ & 2.96 & Netral \\
\hline A.7 & $\begin{array}{l}\text { Penglihatan anda bila } \\
\text { dekat dengan jendela } \\
\text { masjid }\end{array}$ & 2.60 & Nyaman \\
\hline
\end{tabular}

Table 7. Tabel Rekapitulasi Kenyamanan Visual dalam Beraktivitas

\begin{tabular}{|l|l|c|l|}
\hline Kode & \multicolumn{1}{|c|}{ Pertanyaan } & Nilai & Kategori \\
\hline B.1 & $\begin{array}{l}\text { Pencahayaan alami } \\
\text { yang anda rasakan } \\
\text { saat membaca Al- } \\
\text { Qur'an. }\end{array}$ & 3.28 & Netral \\
\hline B.2 & $\begin{array}{l}\text { Yang anda rasakan } \\
\text { saat membaca Al- } \\
\text { Qur'an dibawah } \\
\text { skylight atap. }\end{array}$ & 2.92 & Netral \\
\hline B.3 & $\begin{array}{l}\text { Yang anda rasakan } \\
\text { pada saat } \\
\text { melaksanakan sholat } \\
\text { di dekat jendela. }\end{array}$ & 3.32 & Netral \\
\hline
\end{tabular}

Hasil rekapitulasi kenyamanan visual menunjukkan bahwa pada Masjid Jami'e Darussalam menghasilkan kenyamanan visual yang Netral.

\section{KESIMPULAN}

Kesimpulan dalam penelitian ini adalah:

1. Skylight pada Masjid Jami'e Darussalam menghasilkan kuantitas pencahayaan dengan ratarata sebesar 856 lux pada pukul 08.00, 1.016 lux pada pukul 10.00, 1.316 lux pada pukul 12.00, 1.086 lux pada pukul 14.00, dan 995 lux pada pukul 16.00. Tingkat pencahayaan alami yang dihasilkan pada ruang ini dapat memenuhi minimum standar untuk beribadah di masjid sesuai SNI yaitu sebesar 200 lux dan dapat pula memenuhi minimum standar untuk membaca Al-Quran sesuai dengan SNI yaitu 350 lux. Dari segi kualitas pencahayaan, Skylight pada Masjid Jami'e Darussalam menghasilkan kontras pencahayaan yang masih memenuhi SNI yaitu memiliki nilai tidak kurang dari 1:40, yang berarti Masjid Jami'e Darussalam, tidak berpotensi menghasilkan kontras pencahayaan. Sedangkan keseragaman cahaya, untuk menghasilkan pencahayaan yang seragam, maka minimum nilai keseragaman cahaya adalah 0.6. Sedangkan Masjid
Jami'e Darussalam memiliki nilai dibawah standar keseragaman cahaya.

2. Persepsi responden terhadap tingkat penyilauan pada beberapa titik di Masjid Jami'e Darussalam adalah hanya terdapat satu spot silau yaitu pada spot B. Spot B menghadap kearah Barat sebelah kiri dari mimbar. Namun, secara keseluruhan responden menghasilkan rata-rata Netral terhadap tingkat penyilauan di Masjid Jami'e Darussalam. Persepsi responden terhadap kenyamanan responden dalam melihat keadaan sekitar masjid menghasilkan nilai Netral. Sedangkan persepsi responden terhadap kenyamanan responden dalam beraktifitas, baik untuk sholat maupun untuk membaca Al-Quran menghasilkan nilai Netral.

Dari kedua kesimpulan tersebut, Skylight pada Masjid Jami'e Darussalam memiliki efektivitas yang baik dalam segi kuantitas dan kualitas cahaya serta dapat dirasakan nyaman dalam visual oleh responden..

\section{PERSEMBAHAN}

Terima kasih kepada Universitas Mercu Buana dan pengelola Gedung Masjid Jami'e Darussalam atas dukungannya sehingga penelitian ini bisa berjalan dengan baik.

\section{DAFTAR PUSTAKA}

Heschong, Lisa (2002) :Daylighting And Human Performance.ASHRAE Journal.

IESNA (2010) : The IESNA Lighting Handbook Reference \& Application edisi 9. Illuminating Engineering Society of North America, New York.

Irianto, C. G. (2006). Studi optimasi sistem pencahayaan ruang kuliah dengan memanfaatkan cahaya alam. Jurusan Teknik Elektro-FTI, Universitas Trisakti. Jakarta: Jetri, 5, 1-20.

Kantun, S. (2017). Penelitian Evaluatif Sebagai Salah Satu Model Penelitian Dalam Bidang Pendidikan (Suatu Kajian Konseptual). JURNAL PENDIDIKAN EKONOMI: Jurnal Ilmiah Ilmu Pendidikan, Ilmu Ekonomi dan Ilmu Sosial, $10(2)$.

Konis, K. (2013). Evaluating daylighting effectiveness and occupant visual comfort in a side-lit openplan office building in San Francisco, California. Building and Environment, 59, 662-677.

Massikki, M. N. (2011). Desain Akustik Ruang Sholat Masjid Agung Darussalam Palu. JURNAL ARSITEKTUR, 3(1).

Nasional, B. S. (2004). SNI 16-7062-2004 tentang Pengukuran Intensitas Penerangan di Tempat Kerja. Badan Standarisasi Nasional, Jakarta. 
Nasional, B. S. (2011). SNI SNI 6197:2011 tentang Konservasi Energi pada Sistem Pencahayaan.

Pertiwi, Andika Putri \& Gunawan, Ahmad Nursheha.(2016) Pengaruh Kenyamanan Visual Melalui Pencahayaan Buatan Pada Masjid Syamsul Ulum Universitas Telkom Bandung. Jurnal I D E A L O G Jurnal Desain Interior \& Desain Produk, Vol.1 No.2, Agustus 2016. p.129-145.

Veitch, J. A. (2006). Lighting For High-Quality Workplaces. In: Clements-Croome, Derek (Ed.), Creating the Productive Workplace, seconded.Taylor \& Francis, London, pp. 206222.

Vidiyanti, Christy; dkk. (2018) Kualitas Pencahayaan Alami Dan Penghawaan Alami Pada Bangunan Dengan Fasade Roster (Studi Kasus: Ruang Sholat Masjid Bani Umar Bintaro). Vitruvian: Jurnal Arsitektur, Bangunan, dan Lingkungan. Vol.7 No.2 Februari 2018 p.99-106.

Wisnu \& Indarwanto, M. (2017) Evaluasi Sistem Pencahayaan Alami Dan Buatan Pada Ruang Kerja Kantor Kelurahan Paninggilan Utara, Ciledug, Tangerang. Vitruvian: Jurnal Arsitektur, Bangunan, dan Lingkungan. Vol.7 No.1 Oktober 2017 p.41-46.

Zainurrahman, Aris; dkk. (2012) Kualitas Pencahayaan Alami Masjid Di Lingkungan Perkotaan Padat Penduduk, TEMU ILMIAH IPLBI 2012 p.89-92. 